\title{
PRENATAL DIAGNOSIS OF ISOVALERIC ACIDAEMIA BY ENZYME AND METABOLITE ASSAY IN THE FIRST AND SECOND TRIMESTERS
}

\author{
W. J. KLEIJER*, M. VAN DER KRAAN*, J. G. M. HUIJMANS*, C. M. M. VAN DEN HEUVEL $\dagger$ AND C. JAKOBS $\dagger$ \\ *Department of Clinical Genetics, Erasmus University, Rotterdam, The Netherlands; + Department of Pediatrics, \\ Free University Hospital, Amsterdam, The Netherlands
}

Received 2 November 1994 Accepted 28 January 1995

\begin{abstract}
SUMMARY
Isovaleric acidaemia (IVA) is caused by a deficiency of isovaleryl CoA dehydrogenase. The diagnosis can be established biochemically by the demonstration of increased levels of isovalerylglycine (IVG) and 3-hydroxyisovaleric acid in urine and by the deficiency of incorporation of radiolabel from $\left[{ }^{14} \mathrm{C}\right]$ isovaleric acid in macromolecules in cultured fibroblasts. This paper reports a consecutive series of 24 prenatal diagnoses in pregnancies at high risk, using both methods-metabolite and indirect enzyme assay. Affected fetuses were diagnosed in four pregnancies: three in the second trimester and one recent case in the first trimester. The latter represents the first reported case of a first-trimester diagnosis of IVA by direct analysis of chorionic villi. We also report the first demonstration of strongly accumulated IVG in the amniotic fluid in the 12th week of an affected pregnancy.
\end{abstract}

KEY WORDS: Isovaleric acidaemia; prenatal diagnosis; chorionic villi; amniotic fluid; isovaleryglycine.

\section{INTRODUCTION}

Isovaleric acidaemia (IVA; McK 243500) is an autosomal recessive disorder caused by a deficiency of isovaleryl $\mathrm{CoA}$ dehydrogenase (Sweetman and Williams, 1995). Hydrolysis of isovaleryl-CoA leads to the accumulation of toxic isovaleric acid in plasma and to a strongly increased level of the isovalerylglycine (IVG) conjugate in urine.

The acute neonatal form of the disease is characterized by early onset, usually within the first few days of birth, of several features such as feeding refusal, vomiting, dehydration, lethargy and coma, which is often fatal. Dietary restriction of protein intake and administration of glycine and carnitine diminish the recurrence of episodes of severe ketoacidosis, but this may not

\footnotetext{
Addressee for correspondence: Dr W. J. Kleijer, Clinical Genetics, Erasmus University, P.O. Box 1738, 3000 DR Rotterdam, The Netherlands.
}

always be prevented, especially following respiratory infections. The diagnosis of IVA, which is often already indicated by the typical 'sweaty feet' odour, is established by the demonstration of high concentrations of IVG and 3-hydroxyisovaleric acid (3-HIVA) in urine (Sweetman and Williams, 1995). The diagnosis may be confirmed by direct assay of isovaleryl CoA dehydrogenase in fibroblasts (Hyman and Tanaka, 1986; Frerman and Goodman, 1985) or indirectly by monitoring the incorporation of $\left[1{ }^{14} \mathrm{C}\right]$ isovaleric acid $\left(\left[{ }^{14} \mathrm{C}\right] \mathrm{Iva}\right)$ into macromolecules (Dubiel et al., 1983).

Prenatal diagnosis of IVA was first reported in two pregnancies at risk by Hine et al. (1986) and more recently in a third case by Dumoulin et al. (1991), both by measurement of metabolites in the amniotic fluid and of $\left[{ }^{14} \mathrm{C}\right] \mathrm{Iva}$ incorporation in cultured amniocytes. First-trimester diagnosis by chorionic villus sampling (CVS) has not yet been reported. 
We report here our experience in a consecutive series of 24 prenatal diagnoses by metabolite measurement in amniotic fluid and $\left[{ }^{14} \mathrm{C}\right] \mathrm{Iva}$ incorporation in chorionic villi (CV), cultured CV cells, and amniocytes. The series includes the first prenatal diagnosis by CVS of an affected fetus in the 11 th week of pregnancy and also the first report of a strongly increased level of IVG in amniotic fluid in the 12 th week.

\section{CASE REPORTS}

Prenatal analyses were performed in 24 at-risk pregnancies of 17 couples from nine different countries. All mothers had given birth to at least one previous child with IVA; the diagnoses had been established locally by clinical features and metabolite analysis in urine, showing strong elevations of IVG and 3-HIVA concentrations. In patients' skin fibroblasts from eight of the families, the diagnosis was confirmed by investigation of the leucine degradation pathway, as described below.

CVS and amniocentesis in Dutch cases were performed at the University Hospital, Dijkzigt, Rotterdam (three at-risk cases and most of the controls) and in Groningen (one case). In all the other cases, fresh $\mathrm{CV}$ in culture medium, cultured CV cells, or unprocessed amniotic fluid (AF) samples were sent, usually by air, within $24 \mathrm{~h}$ to Rotterdam; cell-free AF was sent frozen in dry ice to Amsterdam either from Rotterdam or directly from the original place of sampling.

\section{MATERIALS AND METHODS}

\section{Chorionic villi and cell cultures}

CV were sampled in the 10th-12th week of pregnancy, separated from maternal decidua and mucus, selected, and transported in culture medium to the laboratory. Upon arrival at our laboratory, the CV were inspected again under a microscope. CV cells, AF cells, and skin fibroblasts were cultured in Ham's F10 medium with 15 per cent fetal calf serum and antibiotics in a humidified $\mathrm{CO}_{2}$ ( 3 per cent) incubator. $\mathrm{CV}$ cells and amniocytes from the second or third passage were used for the assays. In each assay of CV or cultured CV cells or amniocytes from pregnancies at risk, normal control CV or cultures of corresponding cell types were included; moreover, all assays included normal control fibroblasts and at least one cell strain from a previously studied IVA patient.
Control CV were taken from abundant samples obtained for chromosome analysis only.

\section{$\left[1-^{14} \mathrm{C}\right]$ Isovaleric acid incorporation into macromolecules}

The activity of isovaleryl CoA dehydrogenase was indirectly assayed by the so-called macromolecular labelling test described by Dubiel et al. (1983), measuring the incorporation of $\left[{ }^{14} \mathrm{C}\right] \mathrm{Iva}$ in a macromolecular fraction in intact cultured cells or CV. For triplicate assays of cell cultures, $2.5 \times 10^{5}$ cells were seeded in three dishes ( $35 \mathrm{~mm}$ diameter). For CV samples, six dishes were provided with several small villus fragments $(2-5 \mathrm{mg}$ per dish). After overnight incubation, the culture medium was replaced by $2 \mathrm{ml} /$ dish medium containing $1 \mu \mathrm{Ci} / \mathrm{ml}$ $\left[1-{ }^{14} \mathrm{C}\right]$ isovaleric acid $(50-60 \mathrm{mCi} / \mathrm{mmol} ; \mathrm{ARC}$, St Louis, U.S.A.) and $2 \mu \mathrm{Ci} / \mathrm{ml} \mathrm{L}-\left[4,5-{ }^{3} \mathrm{H}\right]$ leucine (130-190 Ci/mmol; Amersham). The dishes were incubated for $48 \mathrm{~h}$ at $37^{\circ} \mathrm{C}$. Cells were harvested by trypsinization $(0.25$ per cent), taken up in culture medium, centrifuged for $5 \mathrm{~min}$ at $1000 \mathrm{rpm}$, and the pellets washed twice in phosphate-buffered saline, $\mathrm{pH} 7.4$ (PBS). Ice-cold trichloroacetic acid (TCA; $0.5 \mathrm{ml} 5$ per cent) was added to each pellet, which was then suspended vigorously and kept on ice for $10 \mathrm{~min}$ and centrifuged for $10 \mathrm{~min}$ at $3000 \mathrm{rpm}$. After a second TCA precipitation step, the pellet was suspended in $200 \mu \mathrm{l}$ of $1 \mathrm{~N} \mathrm{NaOH}$ and kept at room temperature for $30 \mathrm{~min}$. CV samples were treated similarly, except that they were washed at least four times in PBS. After all PBS washings and TCA precipitations, CV were not pelleted by centrifugation, but by removing the fluids with Pasteur pipettes. For complete solubilization, the CV 'precipitates' were kept in $200 \mu \mathrm{l}$ of $1 \mathrm{~N} \mathrm{NaOH}$ for $30 \mathrm{~min}$ at $60^{\circ} \mathrm{C}$. Aliquots of $100 \mu \mathrm{l}$ of the resulting solutions were used for counting radioactivity in $5 \mathrm{ml}$ of Hionic (Packard). The remainder of the solutions was used for protein assay using the BCA method (Smith et al., 1985).

The incorporation of ${ }^{14} \mathrm{C}$ in all tests is expressed as $\mathrm{dpm}$, both per $\mu \mathrm{g}$ protein and per $\mathrm{dpm}{ }^{3} \mathrm{H}$ from $\left.{ }^{3} \mathrm{H}\right]$ leucine. However, as more variation is found when ${ }^{14} \mathrm{C}$ incorporation is expressed as $\mathrm{dpm} / \mu \mathrm{g}$, all results in this paper are presented as the ratios of $\operatorname{dpm}{ }^{14} \mathrm{C} /{ }^{3} \mathrm{H}$.

\section{Determination of isovalerylglycine in amniotic fluid}

The quantitation of IVG in amniotic fluid supernatant was performed by stable isotope dilution gas chromatography/mass spectrometry according to the procedure of Hine et al. (1986). 
Table $\mathrm{I}-\left[{ }^{14} \mathrm{C}\right] \mathrm{Is}$ sovaleric acid incorporation in cells of isovaleric acidaemia patients and controls

\begin{tabular}{|c|c|c|c|c|}
\hline \multicolumn{2}{|c|}{ Controls } & \multicolumn{3}{|c|}{ Isovaleric acidaemia patients } \\
\hline & $\begin{array}{c}{ }^{14} \mathrm{C}^{3} \mathrm{H} \text { ratio* } \\
\text { Range and } \\
\text { mean } \pm \mathrm{SD}\end{array}$ & & $\begin{array}{c}{ }^{14} \mathrm{C} /{ }^{3} \mathrm{H} \text { ratio* } \\
\text { Range and } \\
\text { mean } \pm \mathrm{SD}\end{array}$ & $\begin{array}{l}\text { Percentage } \\
\text { Range and } \\
\text { mean } \pm \text { SD }\end{array}$ \\
\hline Fibroblasts & & Fibroblasts & & \\
\hline 24 controls & $\begin{array}{l}19-71 \\
33 \pm 12\end{array}$ & 16 patients & $\begin{array}{c}1 \cdot 5-5 \cdot 7 \\
3 \cdot 6 \pm 1 \cdot 2\end{array}$ & $\begin{array}{c}6-17 \\
11 \cdot 2 \pm 2 \cdot 9\end{array}$ \\
\hline $\begin{array}{l}\text { Control } 1 \\
\text { (7 assays) } \\
\text { Control } 2 \\
(8 \text { assays })\end{array}$ & $\begin{array}{l}13-52 \\
27 \pm 13 \\
18-49 \\
31 \pm 9\end{array}$ & $\begin{array}{l}\text { Patient } O \\
\text { (17 assays) }\end{array}$ & $\begin{array}{c}1 \cdot 0-5 \cdot 5 \\
2 \cdot 3 \pm 1 \cdot 3\end{array}$ & $\begin{array}{c}5-17 \\
10 \cdot 3 \pm 4 \cdot 0\end{array}$ \\
\hline Chorionic villi & & Chorionic villi & Ratio & Percentage \\
\hline 8 controls & $\begin{array}{l}105-223 \\
178 \pm 40\end{array}$ & Case $1 \ddagger$ & $7 \cdot 2$ & $3 \cdot 3$ \\
\hline$C V$ coll & & CV cells & & 5.5 \\
\hline 9 controls & $\begin{array}{l}10-69 \\
35 \pm 22\end{array}$ & $\begin{array}{l}\text { Case } 6 \\
\text { Amniocytes }\end{array}$ & $\begin{array}{l}3.5 \\
5.5\end{array}$ & $\begin{array}{r}5.5 \\
11.5\end{array}$ \\
\hline Amniocytes & & Case 1 & 1.8 & $3 \cdot 8$ \\
\hline 18 controls & $\begin{array}{l}15-74 \\
44 \pm 18\end{array}$ & $\begin{array}{l}\text { Case } 6 \\
\text { Case } 15\end{array}$ & $\begin{array}{l}4 \cdot 6 \\
2 \cdot 2\end{array}$ & $\begin{array}{r}10 \cdot 0 \\
2 \cdot 7\end{array}$ \\
\hline
\end{tabular}

\footnotetext{
${ }^{*}$ Ratio of dpm ${ }^{14} \mathrm{C} /{ }^{3} \mathrm{H} \times 10^{3}$ incorporated per $48 \mathrm{~h}$ from $\left[1-{ }^{14} \mathrm{C}\right]$ isovaleric acid and $\left[{ }^{3} \mathrm{H}\right] \mathrm{leucine}$, respectively.

$f\left[{ }^{14} \mathrm{C}\right]$ Isovaleric acid incorporation $\left({ }^{14} \mathrm{C} /{ }^{3} \mathrm{H}\right.$ ratio $)$ in patients as a percentage of intra-assay controls.

$\ddagger$ Case numbers as in Table II.
}

\section{RESULTS}

$\left[^{14} \mathrm{C}\right]$ Isovaleric acid incorporation in cells from isovaleric acid acidaemia patients and controls

The $\left[{ }^{14} \mathrm{C}\right] \mathrm{Iva}$ incorporation test has been applied for more than 10 years without essential methodological changes. In all assays cultured fibroblasts of control individuals and IVA patients were included. Table I shows the results from this whole period for 24 different control fibroblast strains and for two other controls which have been repeatedly tested (seven and eight times, respectively). The ranges for the two repeatedly tested cell strains are not very different from the ranges for the 24 different controls. By contrast, triplicates for each cell strain within one assay show variations of no more than a few per cent. These results suggest that the inter-assay variation (including culture conditions) is greater than the variation between individuals.

A similar conclusion may be drawn from the results for IVA patients' cell strains (Table I). One cell strain (patient $O$ ) was used as the standard patient control in 17 different assays: the range of the incorporation level, the mean, and the standard deviation (SD) were not different from the results for 16 different IVA patients. The incorporation levels for patients' cell strains are reduced to approximately 10 per cent of the level of incorporation in controls. The inter-assay variation is somewhat diminished when the incorporation in IVA patients is expressed as a percentage of the level in one or two intra-assay controls (Table I, right-hand column); the mean level in patients remains at approximately 10 per cent. There was no consistent evidence that some IVA cell lines have a higher or lower incorporation rate than others.

Cultured CV cells and amniotic fluid cells from normal control pregnancies had similar ${ }^{14} \mathrm{C} /{ }^{3} \mathrm{H}$ incorporation ratios to those of cultured fibroblasts. However, the incorporation ratio in uncultured CV is significantly higher than in cultured cells (Table I). Results on CV cells and amniocytes 
Table II-Prenatal diagnoses for isovaleric acidaemia in 24 at-risk pregnancies by (indirect) enzyme analysis and metabolite measurement

\begin{tabular}{|c|c|c|c|c|c|c|c|}
\hline \multirow[b]{2}{*}{ Case* } & \multicolumn{4}{|c|}{$\begin{array}{c}{\left[{ }^{14} \mathrm{C}\right] \text { Iva incorporation }} \\
\% \text { of intra-assay control(s) }\end{array}$} & \multirow{2}{*}{\multicolumn{2}{|c|}{$\begin{array}{l}\text { Iva-glycine } \\
(\mathrm{nmol} / \mathrm{l}) \mathrm{AF}\end{array}$}} & \multirow{2}{*}{$\begin{array}{c}\text { Prenatal } \\
\text { diagnosis } \\
\text { and TOP† }\end{array}$} \\
\hline & Proband & $\mathrm{CV}$ & CV cells & AF cells & & & \\
\hline \multicolumn{8}{|l|}{$\begin{array}{l}\text { First trimester } \\
(10-12 \text { weeks })\end{array}$} \\
\hline 1. Li $94 \mathrm{NL}$ & $9 \ddagger$ & 3 & 6 & 4 & 1631 & (12 weeks) & + \\
\hline 2. $\mathrm{Br} 90 \mathrm{NL}$ & 11 & 79 & - & 65 & 19 & (16 weeks) & \\
\hline 3. Mo 91 I & 17 & 143 & 145 & - & - & & \\
\hline 4. $\mathrm{Bi} 93 \mathrm{CH}$ & 13 & 124 & 117 & - & - & & \\
\hline 5. $\mathrm{Te} 92 \mathrm{D}$ & $-\S$ & - & 54 & - & - & & \\
\hline 6. De $89 \mathrm{~F}$ & $13 \S$ & - & 10 & 9 & 4323 & $(16$ weeks $)$ & + \\
\hline \multicolumn{8}{|l|}{$\begin{array}{l}\text { Second trimester } \\
\text { (14-17 weeks) }\end{array}$} \\
\hline 7. $\mathrm{Sa} 82 \mathrm{NL}$ & $12 \S$ & & & 118 & $<50$ I & & \\
\hline 8. Sa $84 \mathrm{NL}$ & $12 \S$ & & & 122 & $<509$ & & \\
\hline 9. Su $84 \mathrm{CS}$ & $12 \S$ & & & 59 & 50 & & \\
\hline 10. Su $86 \mathrm{CS}$ & $12 \S$ & & & 99 & 80 & & \\
\hline 11. Ha $89 \mathrm{~F}$ & - & & & 63 & 5 & & \\
\hline 12. $\mathrm{Su} 91 \mathrm{ISR}$ & $8 \S$ & & & 284 & 19 & & \\
\hline 13. Ov 91 ISR & $-\S$ & & & 100 & 10 & & \\
\hline 14. Ov 93 ISR & $-\S$ & & & 158 & 19 & & \\
\hline 15. Te $94 \mathrm{D}$ & $-\S$ & & & 3 & 6358 & (16 weeks) & + \\
\hline 16. Ve $88 \mathrm{E}$ & - & & & & 10 & & \\
\hline 17. $\mathrm{Cl} 89 \mathrm{~GB}$ & - & & & & 33 & & \\
\hline 18. Ov 90 ISR & $-\S$ & & & & 12 & & \\
\hline 19. Du $91 \mathrm{~F}$ & - & & & & $1129 \|$ & (18 weeks) & + \\
\hline 20. De $92 F$ & $13 \S$ & & & & 24 & & \\
\hline 21. Gü $93 \mathrm{D}$ & - & & & & 29 & & \\
\hline 22. $\mathrm{Ba} 93 \mathrm{E}$ & - & & & & 17 & & \\
\hline 23. Su 94 ISR & $8 \S$ & & & & 28 & & \\
\hline 24. Be $94 \mathrm{~GB}$ & - & & & & 48 & & \\
\hline
\end{tabular}

*Initials, year, and origin (country) of samples.

$\dagger$ Termination of pregnancy $(+)$ or born and not affected.

$\ddagger$ Fibroblasts of proband in family; case 1 fetus after TOP.

$\S$ Multiple pregnancies of the same mother investigated.

i|Cases 6 and 19 were also studied in Lyon (Dumoulin et al., 1991).

ICases 7 and 8 , qualitative metabolite analysis.

from affected pregnancies are indicated in the right-hand part of Table I and will be elucidated below.

\section{First-trimester analysis of chorionic villi and amniotic fluid}

Six pregnancies at risk were studied in the first trimester. In cases 1-4, listed in Table II, CV were directly analysed after arrival from our hospital (cases 1 and 2) or from Genova, Italy (case 3) and Zürich, Switzerland (case 4). In each case, six small portions of CV fragments were selected and tested separately as described in the Materials and Methods section. Six to 12 small portions of $\mathrm{CV}$ fragments from two control pregnancies (at risk for chromosome aberrations) served as intra-assay controls; in cases 3 and 4, one of the two control samples was sent together with the at-risk sample from abroad, while the second sample was from our own centre. The results of all separate measurements are presented in Fig. 1. All CV fragments from pregnancy 1 showed severe deficiency of incorporation of radiolabel from $\left[{ }^{14} \mathrm{C}\right] \mathrm{Iva}$, while 


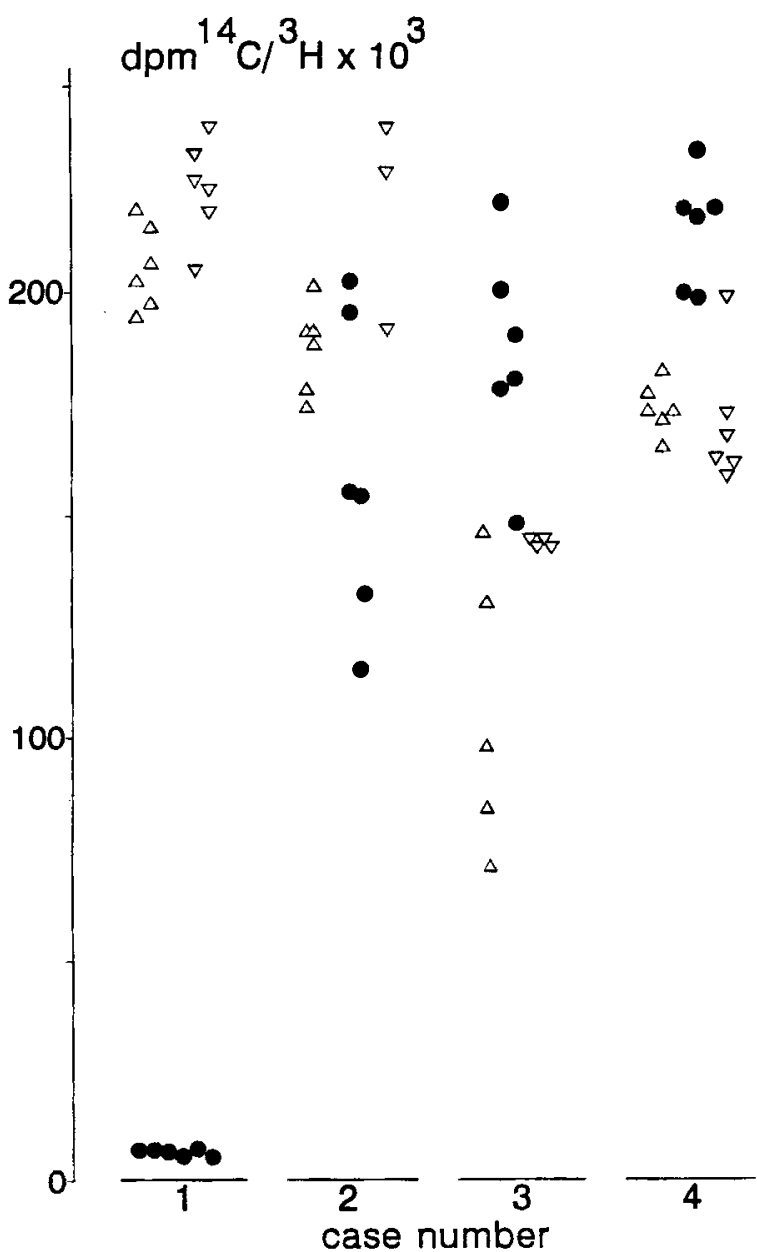

Fig. $1-\left[1-{ }^{14} \mathrm{C}\right]$ Isovaleric acid incorporation in macromolecules in intact chorionic villi from four pregnancies at risk (O) and eight controls $(\nabla ; \Delta)$. Three to six samples from each pregnancy were separately investigated

a high incorporation of $\left[{ }^{3} \mathrm{H}\right]$ leucine indicated normal protein synthetic activity in these villus fragments (i.e., the ${ }^{14} \mathrm{C}^{3} \mathrm{H}$ ratio in case 1 is very low compared with the controls, Fig. 1). The mean incorporation ratio for the villi from the pregnancy at risk was 3 per cent of the mean ratio for the controls. An unequivocal diagnosis of an affected fetus could be made 3 days after CVS. At termination at the end of the 12th week of pregnancy, amniotic fluid was sampled to allow metabolite measurements in the fluid at that early stage. The concentration of IVG was $1631 \mathrm{nmol} / \mathrm{l}$, which is 50-100 times the control level (controls at 12-13 weeks, $n=3 ; 1-54 \mathrm{nmol} / \mathrm{l})$. Further confirmation of the prenatal diagnosis was obtained by $\left[{ }^{14} \mathrm{C}\right] \mathrm{Iva}$ incorporation studies in three types of cultured cells: CV cells which had been cultured from the original CV sample, amniotic fluid cells, and fibroblasts grown from fetal skin; the results are summarized in Tables I and II (case 1).

The direct analyses of $\mathrm{CV}$ in cases $2-4$ are shown in Fig. 1 and Table II as well: normal incorporation levels were confirmed in cultured CV cells in cases 3 and 4, and as CV cells did not grow well, by amniocentesis in case 2 (Table II). In cases 5 and 6, we were consulted only after CVS. Cultured CV cells in case 5 exhibited a slightly reduced, but not deficient, level of $\left[{ }^{14} \mathrm{C}\right] \mathrm{Iva}$ incorporation; as the fetus was female, the presence of maternal cells could not be excluded and amniocentesis was recommended, but this was not carried out. As predicted, the children born from pregnancies 2-5 were not affected. In case 6, a clear deficiency of $\left[{ }^{14} \mathrm{C}\right]$ Iva incorporation was demonstrated in the CV cells, similar to the level in fibroblasts of the proband (Tables I and II). These results were confirmed by the demonstration of a highly elevated concentration of IVG in amniotic fluid and the deficiency of $\left[{ }^{14} \mathrm{C}\right]$ Iva incorporation in the amniocytes (Tables I and II).

\section{Second-trimester analyses of amniotic fluid and amniocytes}

In 18 pregnancies at risk, prenatal analyses were carried out only after amniocentesis in the 14th17 th week since CVS in these pregnancies was not (yet) possible or not desirable. In all pregnancies the IVG concentration was measured, which was followed by $\left[{ }^{14} \mathrm{C}\right] \mathrm{Iva}$ incorporation testing of amniocytes in the nine cases in which complete amniotic fluid was sampled or sent to Rotterdam; in nine other cases, only cell-free amniotic fluid was sent to Amsterdam.

In two cases (15 and 19 , Table II), very high IVG concentrations were measured: roughly 250 and 40 times the mean control level, respectively. These findings allowed the definitive diagnosis of an affected fetus. Subsequent investigation of cultured amniocytes of case 15 showed severely deficient $\left[{ }^{14} \mathrm{C}\right] \mathrm{Iva}$ incorporation $(3$ per cent of the intra-assay control, Tables I and II); the diagnosis in case 19 was in agreement with parallel studies in Lyon (Table II, footnote $\mid I)$.

In the 16 remaining pregnancies at risk, a nonaffected fetus was indicated by IVG concentrations in the normal range (at 14-17 weeks, $n=80$; 1-66 nmol/1), or only slightly above that range 
(case 10 ), and by normal $\left[{ }^{14} \mathrm{C}\right]$ Iva incorporation when amniocytes were available. None of the children born from these 16 pregnancies was affected with IVA.

\section{DISCUSSION}

Prenatal diagnosis of IVA is possible by the measurement of metabolites in amniotic fluid and by monitoring the leucine catabolic pathway in $\mathrm{CV}$ or amniotic fluid cells. Extremely high IVG concentrations were demonstrated in the amniotic fluid of three not previously reported pregnancies with a fetus affected with IVA. In two of these cases, at 16 weeks of gestation the IVG concentration was 200-300 times the mean control level, which was considerably higher than the levels in the three previously reported cases, which, however, still exhibited a 30- to 60-fold elevated concentration (Hine et al., 1986; Dumoulin et al., 1991). In one other affected pregnancy, we demonstrated a very high IVG concentration in the amniotic fluid as early as 12 weeks of gestation. In all non-affected pregnancies, IVG concentrations were in the normal control range ( 16 cases) or only slightly higher (one case). The distinction between the IVG levels present in the six affected pregnancies reported up to now and those in pregnancies at risk with unaffected fetuses is extremely great. There is no evidence that heterozygosity of either the fetus (a $2 / 3$ chance) or the mother (all cases) has a significant influence on the IVG concentration in the fluid. So, measurement of IVG (and possibly 3-HIVA) in amniotic fluid appears to be a reliable method for the prenatal diagnosis of IVA, which could be applied as early as 12 weeks of gestation.

Whenever complete amniotic fluid or cultured amniocytes were received (12 cases), $\left[{ }^{14} \mathrm{C}\right] \mathrm{Iva}$ incorporation tests were done and the results were in accordance with the metabolite measurements. $\left[{ }^{14} \mathrm{C}\right] \mathrm{I}$ va incorporation in amniocytes was deficient in the three affected cases, i.e., $<10$ per cent of control values, which was clearly distinct from the levels in all other pregnancies with a homozygous normal or heterozygous fetus. The nature of the apparent residual incorporation, which we also found in skin fibroblasts of IVA patients, is not known but could well represent the contribution of other acyl CoA dehydrogenases (Hyman and Tanaka, 1986). The results indicate that $\left[{ }^{14} \mathrm{C}\right] \mathrm{Iva}$ incorporation in amniocytes provides a reliable adjunctive method for prenatal diagnosis, but the disadvantage is that cell cultivation and analysis take at least 3 weeks following amniocentesis. A much earlier diagnosis can be achieved by direct analysis of the fresh, uncultured CV, which may be sampled in the 10th12 th week of pregnancy.

Tests monitoring metabolic pathways in intact CV have been successfully applied for the prenatal diagnosis of several disorders such as citrullinaemia and maple syrup urine disease (Kleijer et al., 1984, 1985). The incorporation of radiolabel from $\left[{ }^{14} \mathrm{C}\right] \mathrm{Iva}$ in proteins requires passage through the leucine catabolic pathway, part of the tricarboxylic acid cycle, and via amino acids and protein synthesis. The high level of ${ }^{14} \mathrm{C}$ incorporation in the present study of CV shows that all these steps are actively functioning in $\mathrm{CV}$ from controls and from the three at-risk pregnancies with normal outcome. By contrast, the CV from an affected fetus exhibited an almost complete deficiency of $\left[{ }^{14} \mathrm{C}\right]$ Iva incorporation. Although the present case represents the first diagnosis of IVA within the first-trimester, the results suggest that the method used allows a reliable diagnosis before 13 weeks and thus termination of pregnancy by suction curettage. The use of cultured CV cells also allows a reliable diagnosis, as was shown in two cases here, but the disadvantage--besides the delay caused by cell cultivation-is that the risk of maternal cell growth is not negligible (e.g., 1-2 per cent; Roberts et al., 1988; our unpublished results). This means that the diagnosis can only be conclusive if an unequivocal deficiency is shown in the cultured cells or, in the case of normal results, if the fetus is male, so that the absence of maternal cells can be demonstrated.

We conclude that the best strategy for an early, rapid, and reliable diagnosis is the direct analysis of intact $\mathrm{CV}$ at $10-12$ weeks, which leaves the option of subsequent testing of cultured CV cells or of amniocentesis and measurement of IVG in the presumably rare case of equivocal results.

Alternatively, amniocentesis can be done at 14-16 weeks, or perhaps even earlier, to achieve a conclusive diagnosis within a few days based on metabolite measurements in the fluid. Confirmation of the diagnosis by $\left[{ }^{14} \mathrm{C}\right]$ Iva incorporation testing of cultured amniocytes seems good practice but should neither delay a termination of pregnancy in the case of a high IVG concentration, nor delay reassurance of the parents in the case of a normal IVG level. 


\section{ACKNOWLEDGEMENTS}

We acknowledge the many colleagues from different countries who sent samples or referred patients to us for pre- and postnatal diagnosis.

\section{REFERENCES}

Dubiel, B., Dabrowski, C., Wetts, R., Tanaka, K. (1983). Complementation studies of isovaleric acidemia and glutaric aciduria type II using cultured skin fibroblasts, J. Clin. Invest., 72, 1543-1552.

Dumoulin, R., Divry, P., Mandon, G., Mathieu, M. (1991). A new case of prenatal diagnosis of isovaleric acidaemia, Prenat. Diagn., 11, 921-922.

Frerman, F.E., Goodman, S.I. (1985). Fluorometric assay of acyl-CoA dehydrogenases in normal and mutant human fibroblasts, Biochem. Med, 33, 38-44.

Hine, D.G., Hack, A.M., Goodman, S.I., Tanaka, K. (1986). Stable isotope dilution analysis of isovalerylglycine in amniotic fluid and urine and its application for the prenatal diagnosis of isovaleric acidemia, Pediatr. Res., 20, 222-226.

Hyman, D.B., Tanaka, K. (1986). Isovaleryl-CoA dehydrogenase activity in isovaleric acidemia fibroblasts using an improved tritium release assay, Pediatr. Res., 20, 59-61.

Kleijer, W.J., Thoomes, R., Galjaard, H., Wendel, U., Fowler, B. (1984). First-trimester (chorion biopsy) diagnosis of citrullinemia and methylmalonic aciduria, Lancet, ii, 1340.

Kleijer, W.J., Horsman, D., Mancini, G.M.S., Fois, A., Boué, J. (1985). First-trimester diagnosis of maple syrup urine disease on intact chorionic villi, $N$. Engl. J. Med., 313, 1608.

Roberts, E., Duckett, D.P., Lang, G.D. (1988). Maternal cell contamination in chorionic villus samples assessed by direct preparation and three different culture methods, Prenat. Diagn., 8, 635-640.

Smith, P.K., Krohn, R.I., Hermanson, G.T., Mallia, A.K., Gartner, F.H., Provenzano, M.O., Fujimoto, E.K., Goeke, N.M., Olson, B.J., Klenk, D.C. (1985). Measurement of protein using bicinchoninic acid, Anal. Biochem., 150, 76-85.

Sweetman, L., Williams, J.C. (1995). Branched chain organic acidurias. In: Scriver, C.R., Beaudet, A.K., Sly, M.D., Valle, D. (Eds). The Metabolic Basis of Inherited Disease, 7th edn, New York: McGraw-Hill, 1387-1422. 